\title{
Editorial
}

Andrew Schmitz ${ }^{1}$

\section{Commodity Storage, Price Stabilization, and Food Security}

\author{
${ }^{1}$ University of Florida, Gainesville, FL, USA, E-mail: aschmitz@ufl.edu
}

DOI: 10.1515/jafio-2019-0053

\section{Commodity Storage under Certainty}

The debate over the role of commodity storage in reducing price instability to the net benefit to society continues. Most of the early literature deals with stocks and price instability under price certainty. Little attention is given to the effects of stockholding on food security. Some of the earlier works based on welfare economics (Just, Hueth, and Schmitz 2004) include Waugh (1944), Oi (1961), Massell (1970), and Hueth and Schmitz (1972). Waugh concludes that consumers prefer price instability. As a result, there are costs from commodity storage used to generate price stability. Likewise, Oi concludes that producers prefer price instability; hence, storage is costly for producers. Massell demonstrates that in a market setting that included producers and consumers, society prefers price stability over instability. However, Schmitz (forthcoming) argues that this need not be the case given that both consumers and producers prefer price instability. His arguments are based on an explanation of why stocks are not achievable (Schmitz 2018a) and that producers prefer price instability regardless of the source of the instability (Schmitz 2018b).

Later literature expanded the analyses to multi-products. For example, Turnovsky, Shalit, and Schmitz (1980) and Schmitz, Shalit, and Turnovsky (1981) using utility maximization models demonstrated that in the case of multi-products, producers, for example, prefer stability for a subset of the commodities produced but not for the entire set. Tisdell (1972) analyzed stock policy under uncertainty and concluded that the welfare gains from stabilization are highly dependent on the degree of market uncertainty. Feder, Just, and Schmitz (1980) presented a theory of the firm model where, under uncertainty, producers have several risk management tools, including storage. (References to additional papers can be found in Wright and Williams (1984)).

\section{Stockholding: The Impact of Agricultural Policy}

Many economists argue that stockholding by the government generates large costs to society. This was especially true for the United States in the late 1990s where the Commodity Credit Corporation (CCC) held excessive grain reserves. The key point is that unlike in the theory of the effects of storage where the free market prevails, U.S. stocks were a result not of storage policies, but rather U.S. farm policy that set the target price for major commodities such as wheat and corn along with loan rates. Given the target prices, the market could not clear because the loan rates were set too high.

Consider Figure 1 which incorporates both a price support and a loan rate policy instrument. In period 1 the equilibrium price and quantity in the absence of government are $p_{s}$ and $q_{1}$. In period 2, the equilibrium price and quantity are $p_{l r}$ and $q^{*}$. Now suppose the government supports price at $p_{s}$ and sets the loan rate at $p_{l r}$. What is the effect of a supply shock that shifts supply from $S_{p}$ to $S_{1}$ ? In the absence of the loan rate, the market would clear at price $p c$. However, with the loan rate in place, there is storage required of $q_{c} q^{*}$, which is equal to the amount $c b$. 


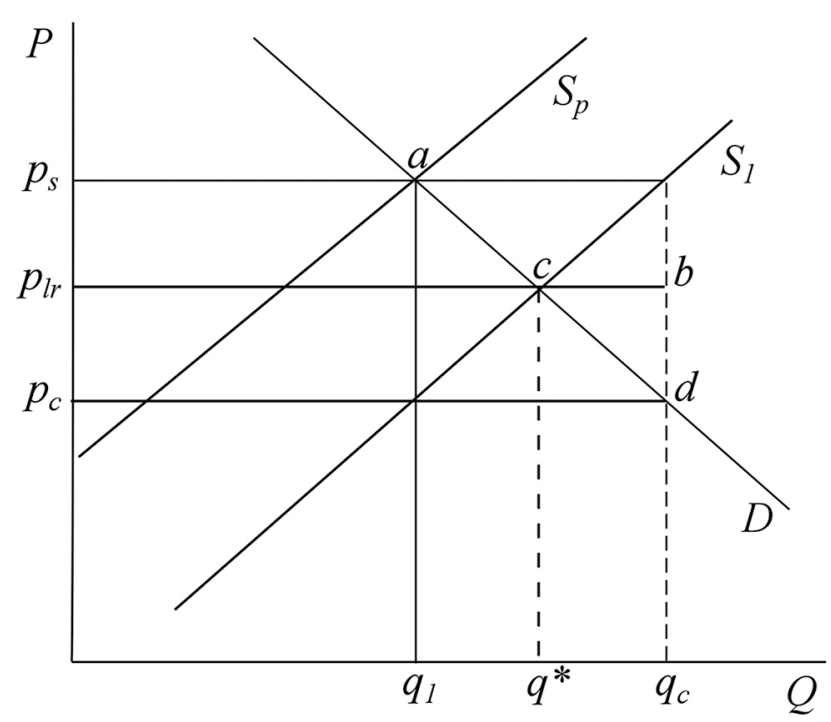

Figure 1: Storage under price supports and loan rates.

\section{Commodity Storage and Food Security in Less Developed Countries}

The topic of commodity storage is generally discussed with reference to less developed economies. Most food storage models do not consider the impact of storage on food security. We review storage models that take into account the food security impact from storage (Schmitz and Kennedy 2016). When food security targets are specified in storage models, the gains from storage can be positive.

\section{Storage and International Trade}

In this volume, storage, price stabilization, and food security in the context of international trade in agricultural products. Most storage models do not take into account how the opening up of trade reduces the need The cost and benefits from storage are discussed using food security indicators. When trade is explicit in the models, the welfare gains from storage are greatly reduced because of food supplies available from exporting counries.

\section{References}

Feder, G., R.E. Just, and A. Schmitz. 1980. “Futures Markets and the Theory of the Firm under Price Uncertainty." Quarterly Journal of Economics 94: 317-28.

Hueth, D.L., and A. Schmitz. 1972. "Trade in Intermediate and Final Coods." Quarterly Journal of Economics 86(3): 351-65.

Just, R.E., D.L. Hueth, and A. Schmitz. 2004. The Welfare Economics of Public Policy: A Practical Approach to Project and Policy Evaluation. Northampton, UK: Elgar.

Massell, B.F. 1970. "Some Welfare Implications of International Price Stabilization." Journal of Political Economy 78(2): 404-17.

Oi, W.Y. 1961. "The Desirability of Price Instability under Perfect Competition." Econometrica 29(1): 58-64.

Schmitz, A. 2018a. "Commodity Price Stabilization under Unattainable Stocks." Theoretical Economic Letters 8: 861-65.

Schmitz, A. 2018b. "Producers' Preference for Price Instability?" Theoretical Economics Letters 8(10): 1746-51.

Schmitz, A. forthcoming. “Does Society Benefit from Price Instability?” Theoretical Economics Letters. 2020.

Schmitz, A., and P.L. Kennedy. 2016. "Food Security and the Role of Food Storage." In Food Security in a Food Abundant World: an Individual Country Perspective, edited by A. Schmitz, P.L. Kennedy, and T.C. Schmitz, 1-18. Bingley, UK: Emerald Croup Publishing.

Schmitz, A., H. Shalit, and S.]. Turnovsky. 1981. "Producer Welfare and the Preference for Price Stability." American Journal of Agricultural Economics 63: 157-60.

Tisdell, C. 1972. "Some Circumstances in Which Price Stabilization by the Wool Commission Reduces Income." Australian Journal of Agricultural Economics 16(3): 94-101.

Turnovsky, S.]., H. Shalit, and A. Schmitz. 1980. “Consumer Surplus, Price Instability, and ConsumerWelfare.” Econometrica 48(1): 135-52.

Waugh, F.W. 1944. "Does the Consumer Benefit from Price Instability?" Quarterly Journal of Economics 58(3): 602-14.

Wright, B.D., and J. Williams. 1984. “The Welfare Effects of the Introduction of Storage.” Quarterly Journal of Economics 99(1): 169-92. 